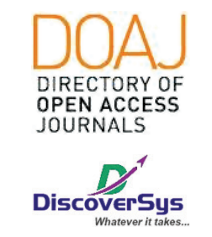

Published by DiscoverSys

\title{
Dislipidemia pada penderita nefropati diabetik di Rumah Sakit Umum Pusat Sanglah Denpasar, Bali tahun 2018
}

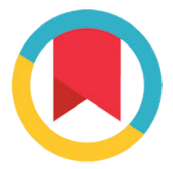

CrossMark

\author{
I Nyoman Santa Wijaya, ${ }^{*}$ Desak Gde Diah Dharma Santhi, ${ }^{2}$ \\ Anak Agung Wiradewi Lestari ${ }^{2}$
}

\section{ABSTRACT}

Background: Diabetic nephropathy is a common complication of diabetes and the main cause of chronic kidney disease in developed countries. Diabetics develop toward nephropathy in about $40 \%$ of cases. This condition is characterized by increased albuminuria or decreased glomerular filtration levels. Patient with diabetic nephropathy and dyslipidemia have higher renal parameters such as blood ureum and serum creatinine.

Aim: The study aims to determine gender, age, blood pressure, smoking habit, and lipid profile, ureum and creatinine characteristic in patients with diabetic nephropathy.

Method: This research was descriptive cross-sectional approach applying 40 patient with diabetic nephropaty who visited Sanglah
General Hospital Denpasar in Januari-Desember 2018. The sampling technique used consecutive sampling techniques and used secondary data in the form of medical records.

Results and Conclusion: Most of diabetic nephropathy patients was male $(55 \%)$, belong to age range of 51 to 60 years $(50 \%)$, had hypertension (55\%) and smoking history (15\%). Lipid profile parameter found that diabetic nephropathy patients had $52 \%$ increase in triglycerides and $62.5 \%$ decrease in HDL levels. Results for urea levels found that $57.5 \%$ samples had urea levels $>23 \mathrm{mg} / \mathrm{dL}$ and $80 \%$ had creatinine levels $>0.90 \mathrm{mg} / \mathrm{dL}$.

Keywords: Diabetic nephropathy, dyslipidemia, ureum, creatinine Cite This Article: Wijaya, I.N.S., Santhi, D.G.D.D., Lestari, A.A.W. 2020. Dislipidemia pada penderita nefropati diabetik di Rumah Sakit Umum Pusat Sanglah Denpasar, Bali tahun 2018. Intisari Sains Medis 11(2): 773-777. D0I: 10.15562/ism.v11i2.689

\section{ABSTRAK}

LLatar Belakang: Nefropati diabetik adalah komplikasi umum dari diabetes dan penyebab utama penyakit ginjal kronis di negara maju. Sekitar 40\% penderita diabetes berkembang ke arah nefropati, dimana kondisi ini ditandai dengan peningkatan albuminuria atau penurunan tingkat filtrasi glomerulus. Penderita nefropati diabetik dengan dislipidemia memiliki parameter ginjal seperti ureum darah dan serum kreatinin yang lebih tinggi.

Tujuan: Untuk mengetahui untuk mengetahui gambaran jenis kelamin, usia, tekanan darah dan riwayat merokok serta profil lipid, ureum dan keratinin pada penderita diabetes mellitus tipe 2 (DMT2) dengan nefropati diabetik.

Metode: Penelitian ini bersifat deskritif dengan metode crosssectional. Sampel penelitian adalah 40 orang penderita nefropati diabetik yang melakukan perawatan di Rumah Sakit Umum Pusat (RSUP) Sanglah Denpasar pada bulan Januari - Desember 2018. Teknik pengambilan sampel dalam penelitian ini menggunakan teknik consecutive sampling dan menggunakan data sekunder berupa rekam medis.

Hasil dan Simpulan: Mayoritas pasien nefropati diabetik adalah berjenis kelamin laki-laki (55\%), dengan umur bekisar 51 - 60 tahun (50\%), mengalami hipertensi (55\%) dan memiliki riwayat merokok (15\%). Gambaran profil lipid pasien nefropati diabetik didapatkan peningkatan trigliserida (52\%) dan penurunan kadar HDL (62,5\%). Hasil untuk parameter kadar ureum mendapatkan sebanyak 57,5\% pasien memiliki kadar ureum $>23 \mathrm{mg} / \mathrm{dL}$ dan sebanyak $80 \%$ memiliki kadar keratinin $>0,90 \mathrm{mg} / \mathrm{dL}$.
Universitas Udayana, Rumah Sakit Umum Pusat Sanglahd Denpasar Bali

${ }^{*}$ Correspondence to:

I Nyoman Santa Wijaya, Program Studi Sarjana Kedokteran dan

Profesi Dokter, Fakultas Kedokteran, Universitas Udayana santhawijaya7@gmail.com

Diterima: $13-01-2020$

Disetujui: 05-07-2020

Diterbitkan: 01-08-2020
Kata kunci: Nefropati diabetik, dislipidemia, ureum, keratinin

Cite Pasal Ini: Wijaya, I.N.S., Santhi, D.G.D.D., Lestari, A.A.W. 2020. Dislipidemia pada penderita nefropati diabetik di Rumah Sakit Umum Pusat Sanglah Denpasar, Bali tahun 2018. Intisari Sains Medis 11(2): 773-777. D0I: 10.15562/ism.v11i2.689

\section{PENDAHULUAN}

Penyakit tidak menular (PTM) seperti penyakit jantung, diabetes mellitus, kanker dan stroke saat ini menjadi permasalahan di masyarakat. Diabetes mellitus merupakan penyakit kelainan metabolik dengan ditandai kadar glukosa darah melebihi kadar normal. ${ }^{1}$ Prevalensi diabetes mellitus diperkirakan 
menempati urutan ke-6 sebagai penyebab kematian dunia. Sekitar 1,3 juta orang meninggal akibat diabetes. Diperkirakan penyandang diabetes di Indonesia pada tahun 2030 akan mencapai sebanyak 21,3 juta jiwa. Penelitian menunjukkan bahwa peningkatan penyakit diabetes pada penduduk Indonesia disebabkan karena kurangnya aktifitas fisik $(26,1 \%)$ penduduk usia $>15$ tahun merupakan perokok aktif $(36,3 \%)$ penduduk $>10$ tahun kurang mengonsumsi buah dan sayur (93\%) serta penduduk $>10$ tahun memiliki kebiasaan minum minuman beralkohol $(4,6 \%)^{2,3}$

Salah satu komplikasi dari diabetes mellitus adalah nefropati diabetik. Nefropati diabetik adalah komplikasi umum dari diabetes dan penyebab utama penyakit ginjal kronis di negara maju. Sekitar $40 \%$ penderita diabetes berkembang ke arah nefropati ditandai dengan peningkatan albuminuria atau penurunan tingkat filtrasi glomerulus. Kondisi nefropati dikaitkan dengan peningkatan risiko penyakit kardiovaskular yang signifikan, chronic kidney disease (CKD), dan kematian dini. Prevalensi nefropati diabetes pada populasi dewasa di Amerika Serikat yang berusia di atas 20 tahun adalah sebesar 3,3\% dan perkiraan jumlah penderita nefropati diabetik di Amerika Serikat adalah 6,9 juta selama tahun 2005-2008. ${ }^{4}$

Diagnosis nefropati diabetik dapat mulai dikenali dengan adanya kejadian albuminuria pada pasien diabetes mellitus tipe I dan tipe II, dimana kandungan albumin di dalam urin mencapai $30 \mathrm{mg} / 24 \mathrm{jam}$ atau $20 \mu \mathrm{g} / \mathrm{menit}$, yang disebut dengan mikroalbuminuria. Kondisi merupakan awal dari diagnosis nefropati diabetika. ${ }^{5}$ Terdapat beberapa faktor yang menyebabkan mikroalbuminuria pada pasien diabetes tanpa dislipidemia seperti peningkatan usia, lamanya diabetes, kontrol glikemik, ureum darah dan serum kreatinin. Parameter ginjal seperti ureum darah dan serum kreatinin pada pasien diabetes dengan dislipidemia didapatkan lebih tinggi pada pasien dengan mikroalbuminuria positif. ${ }^{6}$

Penderita non-insulin dependent diabetes mellitus (NIDDM) dengan mikroalbuminuria menunjukan abnormalitas lipid profil yang dapat meningkatkan resiko penyakit kardiovaskuler. Abnormalitas tersebut meliputi penurunan HDL-K, peningkatankadar kolestrerol total/HDL-K, dan peningkatan kolesterol total rasio yang bila dibandingkan dengan kontrol, terdapat perbedaan bermakna. Kelainan ini mungkin berpengaruh terhadap terbentuknya asterosklerosis. Masalah yang ditimbulkan dari adanya asterosklerosis dapat memberi dampak kecepatan penurunan aliran darah yang disebabkan penyempitan pembuluh darah dan berakhir berkurangnya suplai darah pada ginjal. Hal ini menimbulkan gangguan proses filtrasi di glomerulus dan penurunan fungsi dari ginjal. Masalah ini nantinya merupakan faktor prediktif pada penderita diabetes mellitus untuk berkembang menjadi nefropati dibetik. ${ }^{6}$ Pengukuran untuk mengetahui parameter fungsi ginjal dan progresi penyakitnya adalah glomerular filtratin rate (GFR), yang penurunannya dimana GFR diikuti dengan kenaikan kadar ureum dan keratinin. ${ }^{5}$

Berdasarkan penjambaran diatas maka peneliti tertarik melakukan penelitian mengenai dislipidemia pada penderita nefropati diabetik di RSUP Sanglah. Hasil dari penelitian diharapkan dapat memberikan manfaat informasi mengenai penyakit nefropati diabetik sehingga dapat intervensi dapat dilakukan sedini mungkin.

\section{METODE}

Penelitian ini merupakan penelitian deksriptif cross-sectional untuk mengetahui gambaran jenis kelamin, usia, tekanan darah dan riwayat merokok serta profil lipid, ureum dan keratinin pada penderita diabetes (DMT2) dengan nefropati diabetik. Sampel penelitian adalah penderita nefropati diabetik yang melakukan perawatan di RSUP. Sanglah Denpasar pada bulan Januari Desember 2018. Teknik pengambilan data sampel dilakukan dengan teknik consecutive sampling.

Penelitian ini menggunakan data sekunder dari rekam Medis seluruh pasien nefropati diabetik di RSUP Sanglah Denpasar. Data yang diambil berupa usia, jenis kelamin, tekanan darah, riwayat merokok, kadar trigliserida, kolesterol total, (LDL), (HDL), ureum, dan kreatinin darah. Penelitian dilaksanakan pada September-November 2019. Data yang telah terkumpul selanjutnya diolah dengan menggunakan program Statistical Package for the Social Science (SPSS) versi 23, Microsoft Excel, dan Microsoft Word yang selanjutnya diverifikasi. Data terkumpul kemudian diproses dengan manual, dianalisis secara deskriptif disajikan dalam bentuk tabel dan disertai penjelasan untuk menggambarkan hasil sesuai tujuan penelitian.

Penelitian ini telah mendapat persetujuan dari Komisi Etik Penelitian Kesehatan Fakultas Kedokteran Universitas Udayana/ RSUP Sanglah Denpasar, Bali dengan nomer ethical clearance No.2173/UN14.2.2.VII.14/LP/2019.

\section{HASIL DAN DISKUSI}

Penelitian ini dilaksanakan di RSUP Sanglah Denpasar dan menggunakan data sekunder berupa rekam medis. Jumlah sampel yang didapat adalah 40 sampel. Pemilihan subjek yang diteliti pada diabetes mellitus tipe 2 dengan nefropati diabetik didasarkan pada epidemiologi dari penelitian 
Tabel 1 Distribusi, frekuensi karakteristikk sampell berdasarkan Jenis Kelamin, Usia, Tekanan Darah dan Riwayat Merokok

\begin{tabular}{lcc}
\hline Karakteristik Pasien & Jumlah & $\%$ \\
\hline Jenis Kelamini & & \\
$\quad$ Laki-lakil & 22 & 55 \\
$\quad$ Perempuana & 18 & 45 \\
$\quad$ Totall & 40 & 100 \\
Usiaa (Tahun) & & \\
$\quad<41$ & 1 & 2,5 \\
$41-50$ & 8 & 20 \\
51- 60 & 20 & 50 \\
61- 70 & 11 & 27,5 \\
Total & 40 & 100 \\
Tekanan Darahh & & \\
Hipotensi & 1 & 2,5 \\
Normall & 11 & 27,5 \\
Pre Hipertensii. & 6 & 15 \\
Hipertensi Gradee 1 & 9 & 22,5 \\
Hipertensi Grade 2 & 13 & 32,5 \\
Totali & 40 & 100 \\
Riwayat merokok & & \\
Merokok & 6 & 15 \\
Tidak merokok & 34 & 85 \\
Total & 40 & 100 \\
\hline
\end{tabular}

Tabel 2 Gambaran profil lipid pasien nefropati diabetik

\begin{tabular}{lcc}
\hline Karakteristik Pasien & Jumlah & $\%$ \\
\hline Kolesterol total (mg/dL) & 9 & 22,5 \\
$<140,00$ & 15 & 37,5 \\
$140,00-199,00$ & 16 & 40 \\
$>199,00$ & 40 & 100 \\
Total & & \\
Trigliserida (0mg/dL) & 19 & 47,5 \\
$<0150$ & 21 & 52,5 \\
$>0150$ & 40 & 100 \\
Total & & \\
HDL (mg/dL) & 25 & 62,5 \\
$<040,00$ & 14 & 35 \\
$40,00-65,00$ & 1 & 2,5 \\
$>65,00$ & 40 & 100 \\
Total & & \\
LDL (mg/dL) & 23 & 57,5 \\
$<130$ & 17 & 100 \\
$>130$ & 86 & \\
Total & & \\
\hline
\end{tabular}

sebelumnya dan studi pustaka. Dari beberapa studi mengidentifikasi adanya faktor risiko yang berhubungan nefropati diabetik. Faktor-faktor risiko tersebut adalah : hipertensi, glikosilasi hemoglobin, kolesterol, merokok, faktor usia, resistensi insulin, jenis kelamin, golongan ras, diet tinggi protein dan golongan ras. ${ }^{7}$

Hasil analisis frekuensi karakteristik jenis kelamin pada penelitian ini mendapatkan dari 40 sampel yang mengalami nefropati diabetik di RSUP Sanglah Denpasar sampel menunjukan jumlah tertinggi adalah laki - laki dengan persentase $55 \%$. Penelitian yang dilakukan di Poloklinik Geriatri RSUP Sanglah juga mendapatkan hasil pada kelompok kelamin laki - laki didapatkan banyak mengalami nefropati diabetik. ${ }^{8}$ Pasien DMT2 laki-laki cenderung berkembang ke arah nefropati diabetik lebih cepat dan lebih sering menjalani terapi dialisis di bandingkan wanita. Hormon seks memiliki dampak besar pada metabolisme, fungsi pembuluh darah, dan respon pada peradangan., ${ }^{9,10}$ Penurunan kadar testosteron dan perubahan kadar hormon seks pada pria dapat memperburuk perkembangan nefropati diabetik. Testosteron pria didapatkan dapat mempercepat perkembangan penyakit ginjal kronis. ${ }^{11}$

Hasil analisis frekuensi usia pada pasien nefropati diabetik mendapatkan hasil karakteristik sampel pasien yang paling banyak di umur 51 60 tahun. Penelitian tentang faktor determinan nefropati diabetik, pada penderita diabetes mellitus. yang dilaksanakan di RSUD. DR. M. Soewandhie Surabaya.mendapatkan hasil karakteristik pasien nefropati diabetik terbanyak pada kelompok usia 50-59 tahun. ${ }^{12}$ Hasil penelitian tentang perbedaan dari kejadian komplikasi penderita diabetes melitus tipe 2 menurut gula darah acak di Puskesmas Lidah Kulon. mendapatkan hasil responden kelompok usia $>50$ tahun lebih banyak mengalami nefropati diabetik sebagai salah satu komplikasi diabetes melitus dibandingkan usia $<50 .{ }^{13}$ Faktor yang berpengaruh pada pasien lanjut usia adalah derajat. vasodilatasi yang semakin,tinggi.karena perubahan dari endotel dan peningkatan sintesis nitric oxide sehingga keadaan proteinuria semakin tinggi dan semakin mudah berkembang kearah nefropati diabetik bahkan gagal ginjal. ${ }^{14}$

Hasil analisis frekuensi tekanan darah pada pasien nefropati diabetik di RSUP Sanglah Denpasar mendapatkan hasil karakteristik sampel pasien paling banyak mengalami hipertensi stage 1 dan 2. Penelitian yang dilakukan di RSUP DR. M.Djamil Padang mendapatkan sebesar 70,3\% pasien nefropati diabetik mengalami hipertensi. ${ }^{15}$ Perkembangan hipertensi dan DMT2 dengan 
Tabel 3 Gambaran hasil pemeriksaan ureum dan keratinin

\begin{tabular}{lcc}
\hline Karakteristik Pasien & Jumlah & $\%$ \\
\hline Ureum $(\mathbf{m g} / \mathbf{d L})$ & 4 & 10 \\
$\quad<8$ & 13 & 32,5 \\
$8-23$ & 23 & 57,5 \\
$>23$ & 40 & 100 \\
Total & & \\
Kreatinin (mg/dL) & 2 & 5 \\
$<0,50$ & 6 & 15 \\
$0,50-0,90$ & 32 & 80 \\
$>0,90$ & 40 & 100 \\
Total &
\end{tabular}

nefropati diabetik disebabkan karena berbagai perubahan metabolisme dan hemodinamik. ${ }^{16}$

Riwayat merokok didapatkan pada 6 pasien (15\%) dan 34 pasien lainnya tidak merokok (85\%). Penelitian pada tahun 2016 juga mendapatkan hasil jumlah responden yang tidak merokok lebih banyak dari pada yang merokok. ${ }^{17}$ Merokok pada DMT2 dengan nefropati diabetik merupakan faktor penting dalam perkembangan penyakit nefropati diabetik, CKD dan penyakit kardiovaskular. Hal ini berkontribusi terhadap meningkatnya tingkat transisi dari mikroalbuminuria ke proteinuria dan perkembangan menjadi penyakit ginjal stadium akhir. Komponen utama rokok yaitu nikotin memiliki berbagai efek biologis yang dapat meningkatkan kadar gula darah, dan berpengaruh dalam merangsang kelenjar adrenal yang dapat meningkatkan kadar glukosa. ${ }^{18}$

Dislipidemia adalah kelainan, pada lipid metabolisme yang dengan ditandai adanya penurunan atau peningkatan,fraksi lipid dalam plasma. Kelainan lipid, yang dimaksud meliputi peningkatan kadar kolesterol LDL, trigliserida, kolesterol total, dan serta penurunan kadar, kolesterol HDL. Dislipidemia pada diabetes adalah kondisi yang dapat meningkatkan risiko penyakit kardiovaskular, dan mortalitas. Kadar trigliserida dan kolesterol, tinggi berperan dalam, pembentukan aterosklerosis. Hal, ini menimbulkan proses gangguan di filtrasi glomerulus, berkurangnya suplai darah ke, ginjal, dan penurunan fungsi ginjal hingga selanjutnya dapat, menyebabkan komplikasi penyakit gagal ginjal. ${ }^{1,6}$ Penelitian ini mendapatkan peningkatan kadar trigliserida $(52,5 \%)$ dan penurunan kadar HDL $(62,5 \%)$ pada pasien nefropati diabetes, sedangkan $60 \%$ pasien memiliki kadar kolesterol total normal dan sebagian dibawah rata-rata. Sebesar $57,5 \%$ pasien pada penelitian ini memiliki kadar LDL normal. Penelitian sebelumnya yang dilakukan pada tahun
2012 mendapatkan adanya penurunan HDL pada $56,8 \%$ pasien nefropati diabetik. ${ }^{19}$ Penelitian lainnya mendapatkan hasil peningkatan kadar trigliserida pada $64,9 \%$ penderita nefropati diabetik. ${ }^{14}$ Hal ini disebabkan karena kadar lipid yang tinggi dalam pembuluh darah akan menyebabkan

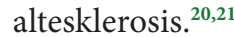

Pasien DMT2 dengan nefropati diabetik perlu untuk melakukan pemeriksaan berupa blood urea nitrogen (BUN), dan kreatinin merupakan cara paling sederhana untuk memantau fungsi ginjal. Ureum adalah produk nitrogen yang dibentuk di hati dan dikeluarkan melalui ginjal. Metabolit ini pada DM tidak diekskresikan secara normal, dan akan menumpuk di tubuh sehingga menyebabkan peningkatan kadar urea dalam darah. Kreatinin adalah, produk metabolisme yang memiliki molekul lebih besar, dan pada dasarnya tidak permeabel terhadap membran tubulus. Kreatinin merupakan penguraian produk kreatin., Terdapat pada hampir semua otot sehingga individu dengan massa otot besar dapat memiliki nilai yang lebih tinggi dan kreatin disintesis di hati. Abnormalitas yang, dapat di timbulkan dari ureum dan keratinin darah ini dapat berbahaya, dan kadar keratinin darah yang tinggi menandakan sudah mulai menurunnya fungsi ginjal yang akan mengarah ke gagal ginjal..$^{22}$ Penelitian terdahulu yang dilakukan pada pasien nefropati diabetik di RSUP Sanglah mendapatkan pasien dengan kadar ureum $>23 \mathrm{mg} / \mathrm{dL}$ adalah sebesar $57,5 \%$ dan pasien dengan kadar keratinin $>0,90 \mathrm{mg} / \mathrm{dL}$ adalah sebesar $80 \%$. Penelitian lain mendapatkan hasil terdapatnya hubungan yang bermakna antara hipertrigliseridemia, dengan kadar ureum darah pada penderita nefropati diabetik $(\mathrm{p}=00,016) .{ }^{19}$ Penelitian lainnya mendapatkan kadar kreatinin yang tinggi pada laki-laki yaitu $55,6 \%$ dengan hasil rerata kadar ureum $0163,25 \mathrm{mg} / \mathrm{dl}$, dan rerata kadar kreatinin 011,6 mg/dl. Penelitian tersebut menemukan adanya hubungan antara kadar ureum dan kolesterol LDL $(\mathrm{p}=00,016)$, serta adanya hubungan antara kadar kreatinin dan kolesterol LDL $(\mathrm{p}=00,004) .{ }^{23}$

\section{SIMPULAN}

Gambaran frekuensi distribusi berdasarkan karakteristik sampel jenis kelamin, usia, tekanan darah dan riwayat merokok didapatkan mayoritas adalah laki - laki, berada pada kelompok umur 51-60 tahun, mengalami hipertensi, dan tidak merokok. Gambaran profil lipid sampel berdasarkan kadar kolesterol total, kolesterol LDL, dan trigliserida, serta penurunan kadar kolesterol HDL didapatkan sebagian besar mengalami peningkatan kadar trigliserida, penurunan kadar HDL, 
peningkatan kadar kolesterol total dan kadar LDL yang normal. Gambaran ureum dan keratinin darah mendapatkan sebagian besar pasien memiliki kadar ureum $>23 \mathrm{mg} / \mathrm{dL}$ dan kadar keratinin $>0.90 \mathrm{mg} / \mathrm{dL}$.

\section{DAFTAR PUSTAKA}

1. Perkumpulan Endokrinologi Indonesia (PERKENI) Konsensus pengelolaan dan pencegahan diabetes melitus tipe 2 di Indonesia. PERKENI; 2015. pp. 6-9.

2. Departemen Kesehatan RI. Diabetes Melitus penyebab kematian nomor 6 di dunia: Kemenkes tawarkan solusi cerdik melalui posbindu; 2013 [sumber online]. Diakses tanggal: 9 Juni 2017. Diakses dari: http://www.depkes. go.id/article/print/2383.html.

3. Departemen Kesehatan RI. Hari ginjal sedunia 2016: cegah nefropati sejak dini; 2016. [sumber online]. Diakses tanggal: 9 Juni 2017. Diakses dari: http://www.depkes.go.id/ article/print/16031000001.html.

4. Jing, C. 2014. Diabetes and Kidney Disease, Diabetic Nephropathy: Scope of the Problem. Department of Medicine, Tulane University School of Medicine.Article

5. American Diabetes Association. Nephropathy in diabetes; 2004. [sumber online]. Diakses tanggal: 9 Juni 2017. http:// care.diabetesjournals.org/content/27/suppl_1/s79.

6. Widiana IGR, Sja'bani M, Asdie AH. Profil lipid pada penderita $\mathrm{dm}$ tak tergantung insulin (niddm) yang disertai mikroalbuminuria. Berkala Ilmu Kedokteran. 1994;26(1):21-7.

7. Arsono S. Diabetes melitus sebagai faktor risiko kejadian gagal ginjal terminal; 2005. [sumber online]. Diakses tanggal: 9 Juni 2017. Diakses dari: http://eprints.undip. ac.id/5252.html

8. Ludirdja J. Rerata durasi penderita diabetes melitus terkena nefropati daibetik sejak terdiagnosis diabetes melitus pada pasien di Poliklinik Geriatri RSUP Sanglah. IPTEKMA. 2010;2(1):24-29.

9. Widianti, I.G.A., Wardana, I.N.G., Wirata, G. 2018. Sweet pranajiwa (Sterculia javanica R. Br) seed extract increases spermatogenesis and sexual behavior in mice (Mus musculus). IJBS 12(1): 7-12. DOI:10.15562/ijbs.v12i1.149

10. Wardana, I.N.G., Widianti, I.G.A., Wirata, G. 2018. Testosterone increases corpus cavernous smooth muscle cells in oxidative stress-induced rodents (Sprague-Dawley). Bali Medical Journal 7(2): 313-322. DOI: 10.15562/bmj. v7i2.970

11. Kautzky-willer A, Harreiter J, Pacini G. Sex and gender differences in risk, pathophysiology and complications of type 2 diabetes mellitus. Endocrine Reviews. 2016;37(3):278-316
12. Putri, Rahmadany I. Faktor Determinan nefropati diabetik pada penderita diabetes mellitus di RSUD Dr. M. Soewandhie Surabaya. Jurnal Berkala Epidemiologi. 2015;3(1):109-21.

13. Wulandari O, Martini S. Perbedaan kejadian komplikasi penderita diabetes melitus tipe 2 menurut gula darah acak. Jurnal Berkala Epidemiologi. 2013;1(2):182-91.

14. Blickle JF. Diabetic nephropathy in the elderly: diabetes \& metabolism. Elsevier Masson SAS; 2007. pp.540-55.

15. Harie S, Descoli E, Afriwardi. 2018. Faktor risiko pasien nefropati diabetik yang dirawat di bagian penyakit dalam RSUP DR. M. Djamil Padang. Jurnal Kesehatan Andalas. 2018;7(2):1-15.

16. Nazar, Chaudhary MJ. Mechanism of hypertension in diabetic nephropathy. Journal of Nephropharmacology. 2014;3(2):49-55

17. Dian M, Rismayanti, Ansar J. Faktor Yang Berhubungan Dengan Kejadian Komplikasi DM Pada Penderita DM Di RS IBNU SINA. Departemen Epidemiologi Fakultas Kesehatan Masyarakat Universitas Hasanuddin; 2016.

18. Tristiyanto N. Perbedaan Kadar Gula Darah Pada Perokok Aktif Dan Perokok Pasif Di Kecamatan Madyopuro Tahun 2015; 2015. [sumber online]. Diakses tanggal 9 Juni 2019. Diakses dari: https://adoc.tips/perbedaan-kadar-guladarah-pada-perokok-aktif-dan-perokok-pa.html.

19. Wulandari A. Hubungan displidemia dengan kadar ureum dan keratinin darah pada penderita nefropati diabetic; 2012. [sumber online]. Diakses tanggal: 4 Juli 2019. Diakses dari: https://media.neliti.com/media/ publications/105484-ID-hubungan-dislipidemia-dengankadar-ureum.pdf.

20. Srinidhi R, Prajna K, Tirthal R. Lipid profile in Type 2 diabetes mellitus and in diabetic nephropathy. International Journal of Clinical Biochemistry and Research. 2017;4(4):379-82.

21. Mulyani WRW, Sanjiwani MID, Sandra, Prabawa IPY, Lestari AAW, Wihandani DM, et al. Chaperone-Based Therapeutic Target Innovation: Heat Shock Protein 70 (HSP70) for Type 2 Diabetes Mellitus. Diabetes Metab Syndr Obes. 2020;13:559-568.

22. Dabla PK. Renal function in diabetic nephropathy. World Journal Of Diabetes. 2010;1(2):48-56.

23. Bhagaskara, Liana P, Santoso B. Hubungan kadar lipid dengan kadar ureum \& kreatinin pasien penyakit ginjal kronik di RSUP Dr. Mohammad Hoesin Palembang periode 1 Januari-31 Desember 2013. Jurnal Kedokteran dan Kesehatan. 2015;2(2):223-30.

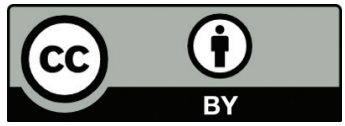

This work is licensed under a Creative Commons Attribution 